\section{Writing community: a humanism curriculum with an academic lens}

\author{
Sigall K. Bell,,2 Edward Krupat, ${ }^{2}$ \\ Sara B. Fazio, ${ }^{1,2}$ Stephen R. Pelletier, \\ Richard M. Schwartzstein, 1,2 \\ David H. Roberts ${ }^{1,2}$ \\ 'Department of Medicine, Beth Israel \\ Deaconess Medical Center; ${ }^{2}$ Harvard \\ Medical School, Boston, MA, USA
}

\begin{abstract}
Explicit teaching of humanism is a goal of education reform, but specific strategies to do so are limited. The authors developed a longitudinal third-year medical student curriculum combining reflective and academic writing with literary reading and reflection to i) improve writing skills, ii) enhance scholarly activities, and iii) foster humanism in patient care. From 2005-2007, 24 third year Harvard Medical School (HMS) participated in a writing program at this hospital. All students completed pre/post surveys and qualitative assessments of the writing program. Students felt better-equipped to access resources $(\mathrm{P}=0.03)$, conduct a literature review $(\mathrm{P}<0.01)$, and understand the meaning of the patient's narrative $(\mathrm{P}<0.01)$ after the program. Their total survey score (assessing writing skills and attitudes) was also significantly higher after the program $(\mathrm{P}=0.02)$. Students described positive effects of writing on self-acceptance, curiosity, and patient-centered care. Of the 24 students, 4 published 5 manuscripts in peer-reviewed journals in the first 2 years of the program. A writing curriculum focusing on humanism is feasible, and can enhance comfort with writing, early publication successes, self-awareness, and perceived humanistic qualities in the interactions of third-year students with their patients.
\end{abstract}

\section{Introduction}

When they ask me, as of late they frequently do, how I have for so many years continued an equal interest in medicine and the poem, I reply that they amount for me to nearly the same thing.

William Carlos Williams

Medical education reform initiatives focus on explicit teaching of humanism and professionalism, but educators often lack specific strategies to achieve this goal. Mentored writ- ing can encourage reflection, represent patients as whole individuals, allow students to make sense of their experiences, support professional development, and facilitate scholarly activities. $^{1-11}$

Degradation of patient-centered attitudes in senior medical students is alarming, ${ }^{12,13}$ and may be attributable to influences of the hidden curriculum, ${ }^{14}$ and/or the role of the null curriculum,${ }^{15}$ wherein topics excluded from the curriculum are deemed by students to be less important. As productivity pressures restrict time for reflection and discussion after clinical encounters ${ }^{16}$ students need bridges between the human story of each illness and the medical facts of each case. ${ }^{17}$

We developed a year-long Reading, Writing, and Reflection (3Rs) curriculum including writing workshops, a book club, and monthly reflection sessions. Here, we share our experience with this curriculum and tools for trying similar innovations in other schools and hospitals.

\section{Innovation}

A total of 24 students completing their third year core clerkships in our hospital during 2005-2007 participated in the 3Rs curriculum. Compared to peers at other affiliated teaching hospitals, the 3Rs students did not show any significant differences in standardized measures of clinical aptitude, or in baseline attitudes and beliefs related to patient care, or career choices. $^{18}$ In 2007, 2.4\% students entered our medical school with a humanities background.

Students each kept a writing portfolio with monthly entries (reflections, case reports, or topical reviews), which were reviewed by faculty, who also led quarterly small group sessions. The entries were intended as foundations for scholarly work. Course faculty were facilitators in other third-year didactic sessions with interest and expertise in writing.

Students participated in 4 writing workshops that incorporated discussion on selected readings (Appendix A) as well as writing exercises focusing on specific cognitive and affective objectives (Table 1). Workshops included inclass writing, visual arts, ${ }^{19}$ and several writing formats including abstracts, short stories, and poetry. Six voluntary book clubs focused on the patient's experience of illness; logic, deduction, and decision-making; cross-cultural aspects of health and disease; leadership; and lay-public perceptions of health (Appendix B). Finally, monthly reflection sessions based on students' written reflections from their writing portfolio provided a forum for group discussion. Students were encouraged, but not required, to submit a written piece to a scholarly journal.
Correspondence: Sigall K. Bell, Beth Israel Deaconess Medical Center, Division of Infectious Diseases, 110 Francis street; LMOB-GB,

Boston, MA 02215, USA.

E-mail: sbell1@bidmc.harvard.edu

Key words: humanism, writing, curriculum, medical student.

Acknowledgement: the authors would like to thank Jacqueline Almeida, Chris Coughlin, Carol Hughes, and the writing instructors for their assistance with the PCE and the writing program; Beth Lown MD, Charlie Hatem MD, Lori Newman MEd, for their guidance and support of the development and implementation of the 3Rs curriculum; the Carl J. Shapiro Institute for Medical Education and Research for support of the program; and the BIDMC PCE students for their numerous insights and contributions.

Funding: this work was funded in part by grant support from the Rabkin Fellowship in Medical Education at BIDMC (SKB), and the Kenneth B. Schwartz Center (SKB).

Conflict of interest: the authors report no conflicts of interest.

Received for publication: 5 October 2010. Revision received: 14 February 2010. Accepted for publication: 14 February 2010.

This work is licensed under a Creative Commons Attribution 3.0 License (by-nc 3.0).

(C) Copyright S.K. Bell et al., 2011

Licensee PAGEPress, Italy

Medical Education Development 2011; 1:e4

doi:10.4081/med.2011.e4

We anticipated the following potential challenges: variable student participation, concern about time away from rotations, and student resistance to writing assignments. To address these, we focused the majority of curricular hours in the early evening or during pre-existing didactic sessions, made the book club voluntary, and compared end-of-year clinical aptitudes with third year students at other teaching hospitals in our medical school, who did not participate in the program. We also included a time-limited approach to writing including 15-minute reflections and in-class writing.

\section{Evaluation}

Students completed surveys containing 18 Likert scale questions at the beginning and end of each academic year, and t-tests were used to compare responses. Five questions addressed baseline experience (ie prior publication), the remaining 13 assessed skills or 
attitudinal changes related to writing. A summary score assessed aggregate growth in skills and attitudes using the 13 skill and attitude questions. Twelve third-year students at our medical school (but not at our hospital) served as controls. As part of a qualitative assessment of the writing curriculum, we asked 3 Rs students to comment on Something I learned about myself or my patient that I didn't know/realize before writing my reflections. The 3 Rs program was approved by the Institution Review Board at our hospital and medical school.

Twenty-four students created writing portfolios consisting of over 250 written pieces. At program entry, all students identified effective writing as an important skill (mean 4.7 on 5 point Likert scale). Most students (95\%) had received no/little previous instruction on medical writing. In addition, $63 \%$ did not feel comfortable performing a literature review, and $80 \%$ did not express comfort with the publication process. Post-curriculum analysis showed improvement in all 13 skill or attitude categories and a higher summary score $(\mathrm{P}=0.02)$. Students felt better-equipped to access resources $(\mathrm{P}=0.03)$, conduct a literature review $(\mathrm{P}<0.01)$, and understand the meaning of the patient's narrative $(\mathrm{P}<0.01$, Figure 1$)$. These findings were also significant when compared to control students. During the first two years of the program, students prepared seven manuscripts for publication; five were accepted for publication in peer-reviewed journals. $^{20-24}$

In the qualitative assessment students noted positive effects of writing on self-acceptance and information mastery, as well as developing career choices and practicing patientcentered care (Table 2). They commented that the curriculum taught them about curiosity, attention to detail, exploring patients' perspectives, and how to provide and receive feedback on writing. Several students noted the value of a writing community - often surprised that their colleagues had experienced similar events or reactions. One student wrote, The readings helped give meaning to my third year... the discussions helped me find peace with my experiences. Common thematic responses included:

Community: I learned a great deal about my classmates and myself, most of all the importance of sharing our experiences and how

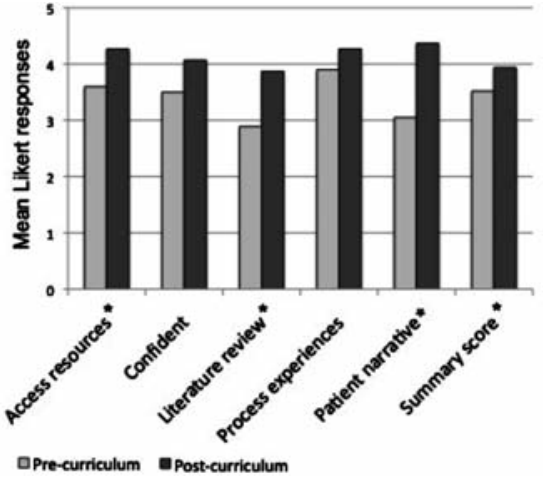

Figure 1. Post-curriculum survey responses showed uniform improvement in all 13 skills and attitude assessments (sample shown); the summary score was statistically higher post-curriculum $(P=0.02)$, as were 3 specific categories $(*)$. Students felt more equipped to access resources $(P=0.03)$, perform a literature review $(P<0.01)$, and understand the role of the patient's narrative $(P<0.01)$. Students were also more confident about writing, and were more likely to report that writing helped them to process their experiences on the wards and that their medical training emphasized humanism in patient care, but these measures did not achieve statistical significance.

Table 1. Sample writing exercises and their objectives.

\begin{tabular}{|c|c|c|}
\hline Exercise & Description & Objective \\
\hline Letter to the Editor & Response to journal article & Cognitive: academic writing skills, use of references \\
\hline Case summary with review of the literature & $\begin{array}{l}\text { Summary of salient features of a clinical case } \\
\text { with discussion of central diagnostic or } \\
\text { management question and relevant } \\
\text { literature review }\end{array}$ & $\begin{array}{l}\text { Cognitive: developing the case report, } \\
\text { use of references, evidence-based medicine }\end{array}$ \\
\hline Topical summary & Review of clinical topic of interest & $\begin{array}{l}\text { Cognitive: developing the review article, } \\
\text { use of references }\end{array}$ \\
\hline HPI versus HPP & $\begin{array}{l}\text { Writing the history of present person } \\
\text { by exploring the individualizing details } \\
\text { of the patient }\end{array}$ & $\begin{array}{l}\text { Affective: seeing the whole person, } \\
\text { contextualizing illness } \\
\text { Cognitive: identifying root cause behaviors } \\
\text { as risk factors }\end{array}$ \\
\hline Dear Illness Letter & $\begin{array}{l}\text { Writing a letter to a particular illness from } \\
\text { the patient's perspective } \\
\text { (ie Dear HIV or Dear Lymphoma) }\end{array}$ & $\begin{array}{l}\text { Affective: identifying with the plight of the patient, } \\
\text { exploring dimensions of illness, increasing empathy }\end{array}$ \\
\hline The first-person HPI (HP1) & $\begin{array}{l}\text { Writing the HPI in the first-person, } \\
\text { as the patient }\end{array}$ & $\begin{array}{l}\text { Affective: understanding illness from the patient's } \\
\text { perspective, incorporating patient explanatory model } \\
\text { and language, improving communication with patient } \\
\text { and family, increasing empathy }\end{array}$ \\
\hline What are you famous for? ${ }^{1}$ & $\begin{array}{l}\text { Writing about patient's response to this } \\
\text { question and the effect of sharing these } \\
\text { individualizing details with the student's team }\end{array}$ & $\begin{array}{l}\text { Affective: seeing the whole person, contextualizing } \\
\text { illness, providing humanizing characteristics } \\
\text { in patient care, reducing patient isolation, } \\
\text { representing the patient's voice }\end{array}$ \\
\hline When were you your best person? & $\begin{array}{l}\text { Writing about a time when the student was } \\
\text { particularly proud of their actions or behavior }\end{array}$ & $\begin{array}{l}\text { Affective: preserving self, maintaining core values } \\
\text { during medical training }\end{array}$ \\
\hline Where are you indispensible? ${ }^{2}$ & $\begin{array}{l}\text { Writing about elements of the student's life that } \\
\text { he/she feels are particularly meaningful, } \\
\text { and where his or her role is critical }\end{array}$ & $\begin{array}{l}\text { Affective: preserving self, maintaining balance } \\
\text { between personal and professional responsibilities }\end{array}$ \\
\hline Reaction to poem, narrative, or music & $\begin{array}{l}\text { A quick writing exercise to explore reactions } \\
\text { to written work or musical trigger }\end{array}$ & $\begin{array}{l}\text { Affective: exploring personal identification with } \\
\text { artistic trigger } \\
\text { Cognitive: learning to write in a short time frame }\end{array}$ \\
\hline Parallel chart 3 personal reflection & $\begin{array}{l}\text { Writing about something that struck the student } \\
\text { related to a patient encounter }\end{array}$ & $\begin{array}{l}\text { Affective: reflection as a vehicle to find meaning, } \\
\text { exploration of ethical dilemmas, conflicts of interest, } \\
\text { or self-identification with patients }\end{array}$ \\
\hline
\end{tabular}

'Kirkpatrick et al, Arch Int Med 2005; ${ }^{2}$ Clever, W J Med 2001; ${ }^{3}$ Charon R, Ann Int Med 2001. 
Table 2. Something I learned about my patients or myself that I didn't realize before writing my reflections.

\begin{tabular}{ll} 
Theme & Student quote \\
$\begin{array}{l}\text { Student well-being } \\
\text { Information mastery }\end{array}$ & Writing helps me to accept myself \\
& $\begin{array}{l}\text { I learned more medical facts by linking them to specific } \\
\text { patients that I wrote about }\end{array}$ \\
\hline Importance of reflective writing & $\begin{array}{l}\text { So many times it was when I sat down to actually write about } \\
\text { something... that I was able to [actually] deeply figure out } \\
\text { what the experience really meant to me } \\
\text { I felt like I could better identify with [patients'] frustrations } \\
\text { regarding the uncertainty of medicine }\end{array}$ \\
\hline Clinical uncertainty & $\begin{array}{l}\text { My interests in public health and patient advocacy became } \\
\text { apparent to me through my reflections }\end{array}$ \\
\hline Career decisions &
\end{tabular}

important it is to reach out to one another. So often in the challenges of third year, we feel we're the only ones going through it, but when you read your classmates' writing and share experiences in group sessions, you realize how common many of the things we struggle with are to everyone's experience. In many ways, I wish some of that were more built into third year and even into internship and residency programs, because I suspect facing challenges alone is something we do at every level...

Attention to detail: From reading and discussing Sherlock Holmes in the beginning of the year, I learned the importance of attention to detail. Observing little pieces of information about your patients - what they have in their rooms, the way they interact with the team and with their families, the way they tell their story - helps not only to bring them alive on paper when you go to write about them, but helps you relate to them, build closer relationships with them, and helps the team to provide them better care...

Feedback: I learned how important it is for me to share my work with others and get their take on it. Each time I heard what other people had read and felt when they looked over my writing gave me new insight into the meaning of the experience I had described and how it could touch people, depending on the background they brought to the reading. The questions [and comments] helped me to articulate better what I was trying to say, ending up often making the pieces much clearer and [of] higher quality.

\section{Innovation insights}

The opportunity to collectively engage in reflective practice helped 3Rs students guard against feelings of isolation - finding and providing support in their writing community. These findings are consistent with previously reported positive outcomes of reflective writing during clinical training. ${ }^{25}$ Rather than being left to their own individual means to seek balance, students, in our experience, benefited from a structure to facilitate reflection. Given the challenges of this liminal year, they often need guidance in reflection. They may also need each other in this process, to make greater sense of their experience, to draw strength from community, and to collectively navigate becoming physicians.

One of the surprising successes of our program was that 5 student manuscripts were published in peer-reviewed journals over the first 2 years of the program. While reflective writing has been used successfully in the past with medical students, ${ }^{4,5,26,27}$ our program is unique in its integration of both reflective and academic writing. Success of academic physicians relies on the ability to write effectively, and yet this skill is seldom taught in medical school. We were also struck that some students linked writing activities to information mastery, which may further broaden appeal of the program.

Courses focused on humanism are often included in the first or second year of medical school, but tend to be under-represented during the third and fourth years, when they may be most critical. Such activities may expose the hidden curriculum, and provide the opportunity to preserve students' empathy and interests in the social determinants of illness. Although not studied separately, the 3 Rs curriculum as part of a larger longitudinal third year experience proved to diminish compassion fatigue. ${ }^{18}$ Rather than isolated sessions in the pre-clinical years, direct and simultaneous integration of reading, writing, and reflection into clinical experiences may help translate humanistic approaches into real-time bedside care. This type of curriculum can provide a natural link to courses like The Healer's Art, ${ }^{28}$ traditionally offered in the pre-clinical years.

Finally, the themes and experiences in students' written reflections can also provide important feedback to clerkship directors, residents, and faculty. More conditioned clinicians may benefit from a glimpse of the moments of humanism as described by students. How do fresh eyes view our (positive and negative) routine practices, and what can be learned from their perspective?

Our writing curriculum is readily adaptable to other sites (Appendices A, B, and Table 1). We hope this report will encourage academic centers to continue efforts to implement humanism into a hectic clinical environment. Conclusions about the effectiveness of the curriculum are limited by the small size of the program and non-randomized format. Given that attitudes related to patient-centered care tend to deteriorate in senior medical students, increases in these attitudes suggests that meaningful change can be accomplished with a humanism curriculum. These potential benefits did not come at the expense of clinical performance, since 3 Rs students performed as well or better than their peers in standard objective measures of clinical aptitude, ${ }^{18}$ suggesting that the limited time away from the wards was not detrimental.

\section{Conclusions}

A humanism curriculum including reading, writing, and reflection exercises is feasible, and can enhance comfort with writing, early experience with publication, self-knowledge and awareness, and perceived humanistic qualities in the interactions of third year medical students with their patients. Just as we emphasize development of good lifelong habits pertaining to history taking, physical exam skills, and data analysis during the third year of medical school, educators should also incorporate an early emphasis on reflective practice. The message that educators view this as an educational priority may prove invaluable in shaping future physicians.

\section{References}

1. Epstein RM. Mindful practice. Jama 1999;282:833-9.

2. Arseneau R. Exit rounds: a reflection exercise. Acad Med 1995;70:684-7.

3. Bolton G. Reflective Practice: Writing and Professional Development. London: Paul Chapman Publishing/Sage; 2001.

4. Brady DW, Corbie-Smith G, Branch WT Jr. "What's Important to You?": The Use of Narratives To Promote Self-Reflection and To Understand the Experiences of Medical Residents. Annals of internal medicine 2002;137:220-3.

5. Branch W, Pels RJ, Lawrence RS, Arky R. Becoming a Doctor - Critical-Incident Reports from Third-Year Medical Students. New Engl J Med 1993;329:1130-2.

6. Branch WT Jr. Use of critical incident reports in medical education. JGIM 2005; 20:1063-7.

7. Charon R. Narrative medicine: form, func- 
tion, and ethics. Annals of internal medicine 2001;134:83-7.

8. Morris C. Why does so much depend upon a red wheelbarrow? What is the point of a medical writing option? Medical education 2001;35:1155-6.

9. Niemi PM. Medical students' professional identity: self-reflection during the preclinical years. Medical education 1997;31.

10. Parsons GN, Kinsman SB, Bosk CL, et al. Between two worlds medical student perceptions of humor and slang in the hospital setting. J Gen Intern Med 2001;16:5449.

11. Coleridge ST, Smith-Barbaro P, Knisley C. A practical method for increasing scholarly activity in an academic family medicine department. Teach Learn Med 2004;16: 181-5.

12. Hojat M, Mangione S, Nasca TJ, et al. An empirical study of decline in empathy in medical school. Medical education 2004;38:934-41.

13. Woloschuk W, Harasym PH, Temple W. Attitude change during medical school: a cohort study. Medical education 2004;38: 522-34.
14. Hafferty FW. Beyond curriculum reform: confronting medicine's hidden curriculum. Acad Med 1998;73:403-7.

15. Nelson MS. Only one type of medical education. Annals of emergency medicine 1992;21:770.

16. Campo R. "The Medical Humanities," for lack of a better term. JAMA 2005;294:100911.

17. Fitzgerald FT. Curiosity. Annals of internal medicine 1999;130:70-2.

18. Bell SK, Krupat E, Fazio SB, et al. Longitudinal pedagogy: a successful response to the fragmentation of the thirdyear medical student clerkship experience. Acad Med 2008;83:467-75.

19. Dolev JC, Friedlaender LK, Braverman IM. Use of fine art to enhance visual diagnostic skills. JAMA 2001;286:1020-1.

20. Kakoza R. The challenges of patient advocacy on the wards: reflections from a thirdyear medical student. Current surgery 2006;63:357-8.

21. Bove R. A deck of cards. Current surgery 2006;63:482.

22. Greenman J. Origami. Journal of surgical education 2007;64:246-7.
23. Maki J, Qualls M, White B, et al. Health impact assessment and short-term medical missions: a methods study to evaluate quality of care. BMC health services research 2008;8:121.

24. Kakoza RM, Vollmer Jr CM, Stuart KE, et al. Pancreatic Adenocarcinoma in the Pregnant Patient: A Case Report and Literature Review. J Gastrointest Surg 2009;13:535-41.

25. Lichstein PR, Young G. "My most meaningful patient". Reflective learning on a general medicine service. J Gen Intern Med 1996;11:406-9.

26. Aronson L, Niehaus B, DeVries CD, et al. Do writing and storytelling skill influence assessment of reflective ability in medical students' written reflections? Acad Med 2010;85:S29-32.

27. Cohn FG, Shapiro J, Lie DA, et al. Interpreting values conflicts experienced by obstetrics-gynecology clerkship students using reflective writing. Acad Med 2009;84:587-96.

28. Remen RN, Rabow MW. The Healer's Art: professionalism, service and mission. Medical education 2005;39:1167-8. 